\title{
Seasonality effect on the allelopathy of cerrado species
}

\author{
Gatti, AB. ${ }^{a}$, Takao, LK. ${ }^{a *}$, Pereira, VC. ${ }^{a}$, Ferreira, AG. ${ }^{b}$ Lima, MIS. ${ }^{b}$ and Gualtieri, SCJ. ${ }^{b}$ \\ aPrograma de Pós-Graduação em Ecologia e Recursos Naturais, Universidade Federal de São Carlos - UFSCar, \\ Via Washington Luís, km 235, CP 676, CEP 13565-905, São Carlos, SP, Brazil

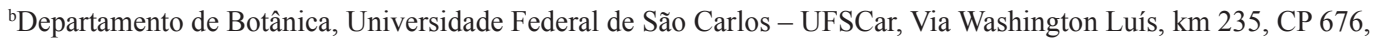 \\ CEP 13565-905, São Carlos, SP, Brazil \\ *e-mail:1ktakao@gmail.com
}

Received: October 2, 2012 - Accepted: June 17, 2013 - Distributed: November 30, 2014

\begin{abstract}
The Brazilian cerrado presents strong climate seasonality. During the dry season, plants may be exposed to stressful situations, such as a soil surface water deficit, that stimulate their chemical defenses. However, the seasonality effect on the production of allelopathic compounds of cerrado plant species is poorly understood. In this study, the phytotoxic activities of common native cerrado plants were evaluated during rainy and dry seasons. Crude leaves extracts ( $10 \%$ concentration: weight/volume, with dry leaves and distilled water) from eleven species were tested on lettuce and sesame germination. The negative effects on germination percentages, rates and informational entropies of the target species were higher when submitted to plant extracts from the dry season, where the germination rate was the most sensible parameter. The higher sensibility of lettuce and the germination rate parameter showed this difference. Only two exceptions had higher effects for rainy season extracts; one species showed higher negative effects on germination informational entropy of lettuce and another species on the germination rate of sesame. Thus, increases in the allelopathic activity were seen in the majority of the studied cerrado plant species during the dry season. These distinct responses to stressful situations in a complex environment such as the Brazilian cerrado may support the establishment and survival of some species.
\end{abstract}

Keywords: chemical ecology, phytotoxicity, secondary metabolites.

\section{Efeito da sazonalidade sobre a alelopatia de espécies de cerrado}

\section{Resumo}

O cerrado brasileiro apresenta forte sazonalidade climática. Durante a estação seca as plantas podem estar expostas a situações estressantes, tais como um déficit de umidade nas camadas superficiais do solo, que estimulam suas defesas químicas. No entanto, o efeito da sazonalidade na produção de compostos alelopáticos de espécies vegetais de cerrado é pouco conhecido. Neste estudo, as atividades fitotóxicas de plantas nativas comuns de cerrado foram avaliadas durante as estações chuvosa e seca. Extratos brutos de folhas (concentração 10\%: peso/volume, com folhas secas e água destilada) de onze espécies foram testados sobre a germinação de alface e gergelim. Os efeitos negativos sobre as porcentagens de germinação, velocidades e entropias informacionais das espécies-alvo foram maiores quando submetidas a extratos vegetais da estação seca. A maior sensibilidade da alface e do parâmetro velocidade de germinação mostraram essa diferença. Apenas duas exceções tiveram maiores efeitos para extratos da estação chuvosa; uma espécie mostrou maiores efeitos negativos sobre a entropia informacional de germinação de alface e outra espécie sobre a velocidade de germinação de gergelim. Assim, aumentos na atividade alelopática foram vistos na maioria das espécies vegetais do cerrado estudadas durante a estação seca. Estas respostas distintas a situações estressantes em um ambiente complexo como o cerrado brasileiro podem auxiliar no estabelecimento e na sobrevivência de algumas espécies.

Palavras-chave: ecologia química, fitotoxicidade, metabólitos secundários.

\section{Introduction}

Climate conditions can regulate plant interactions (Kikvidze et al., 2011). Precipitation regime, temperature, humidity, radiation and soil moisture can affect plant secondary metabolism (Gobbo-Neto and Lopes, 2007; Taiz and Zeiger, 2010) and may relate to plant chemical interactions.
The Brazilian cerrado, the largest savanna in South America, once covered $22 \%$ of the country's land surface (22 million ha), primarily in its Central Plateau. It has a seasonal climate, with a dry season from April to September and a wet season from October to March (Gottsberger and Silberbauer-Gottsberger, 2006). During the former, 
the soil presents a surface water deficit (Haridasan, 2001) that may result in a stressful situation for plants in this environment (Sarmiento, 1996).

Abiotic and biotic stress conditions seemingly improve plant allelopathic activity (Gross, 2003). Allelopathy is defined by the International Allelopathy Society (IAS, 2013) as any process involving secondary metabolites produced by plants, algae, bacteria and fungi that influences the growth and development of agricultural and biological systems. Allelopathy is strongly related to plant-environment interactions (Blanco, 2007). Allelochemicals can benefit or prejudice certain species, influencing the qualitative and quantitative floristic composition in time and space (Durigan and Almeida, 1993). Furthermore, allelopathy may influence forest succession process (Peng et al., 2004) and spatial patterns of species distribution (Inderjit and Callaway, 2003). Allelopathic influence can be expressed on seed germination and/or establishment and development of neighbouring individuals (Ferreira, 2005).

Although seasonal allelopathic variation has been reported, few studies consider this issue for native cerrado species (Oliveira, 2009; Orlandi et al., 2010). It is necessary to examine seasonal allelopathic variation from several species. In this study, the allelopathic potential of eleven cerrado species from nine different families and two different collection periods were assessed to determine the existence and extent of seasonal variation.

\section{Material and Methods}

\subsection{Collection, study area and climate}

Mature plant leaves of eleven cerrado species were collected in a cerrado sensu stricto area of the Universidade

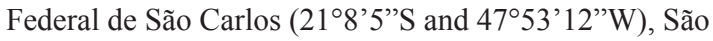
Carlos, São Paulo, Brazil, on 30/03/2006 and 27/07/2006. This area is classified as Cwa (according to Köeppen (1948)) with warm climate and dry winter. The average monthly pluviometry and temperature were $207 \mathrm{~mm}$ and $23^{\circ} \mathrm{C}$ during the rainy season (October 2005 - March
2006) and $18 \mathrm{~mm}$ and $20^{\circ} \mathrm{C}$ during the dry season (April - September 2006) (Embrapa, 2012).

The species studied were Anadenanthera falcata (Benth.) Speg. (Fabaceae), Davilla elliptica A.St.-Hil. (Dilleniaceae), Diospyros hispida A.DC. (Ebenaceae), Kielmeyera coriacea Mart. \& Zucc. (Clusiaceae), Miconia albicans (Sw.) Steud. (Melastomataceae), Piptocarpha rotundifolia Baker (Asteraceae), Schefflera vinosa (Cham. \& Schltdl.) Frodin \& Fiaschi (Araliaceae), Senna rugosa (G.Don) H.S.Irwin \& Barneby (Fabaceae), Siparuna guianensis Aubl. (Monimiaceae), Stryphnodendron polyphyllum Mart. (Fabaceae), and Xylopia aromatica Mart. (Annonaceae) (Ipni, 2012). These species present different habits, shrub or tree (Table 1), and the collection of the leaves was unsystematic.

\subsection{Extract preparation}

The leaves were dried at $55^{\circ} \mathrm{C}$ for 72 hours and stored in plastic bags at ambient temperature until use. Crude extracts ( $10 \%$ concentration: weight/volume) with dry leaves and distilled water were prepared and ground with an industrial blender for approximately one minute. The extracts were stored at an ambient temperature for three hours, filtered using a vacuum pump coupled to a Büchner funnel covered with filter paper $(3 \mu \mathrm{m})$, and tested on the germination of lettuce (Lactuca sativa L.) and sesame (Sesamum indicum L.).

\subsection{Germination bioassay}

Thirty cypselas/seeds of the target species (lettuce/ sesame) were placed in Petri dishes ( $9 \mathrm{~cm}$ diameter) containing a double layer of filter paper $(3 \mu \mathrm{m})$ moistened with $5 \mathrm{~mL}$ of extract or distilled water (witness). All Petri dishes were sealed with PVC film. The lids were closed, and the Petri dishes were placed in a BOD incubator (light-dark cycle of $12 \mathrm{~h}-12 \mathrm{~h}, 20 \pm 1^{\circ} \mathrm{C}$ for lettuce, and $28 \pm 2^{\circ} \mathrm{C}$ for sesame). The germinated cypselas/seeds were counted at $12 \mathrm{~h}$ intervals for one week and at $24 \mathrm{~h}$ intervals until the tenth day of sowing. Seeds with $2 \mathrm{~mm}$ radicular protrusion were considered to be germinated and removed to avoid recounting. At the end of the tenth day, the germination

Table 1. Osmotic potential values (MPa) of the cerrado species crude leaves extracts $(10 \%$ concentration: weight/volume, with dry leaves and distilled water) from rainy and dry seasons.

\begin{tabular}{llcc}
\hline \multicolumn{1}{c}{ Species } & \multicolumn{2}{c}{ Habit } & \multicolumn{2}{c}{ Osmotic potential (MPa) } \\
\cline { 3 - 4 } & & Rainy season & Dry season \\
\hline Anadenanthera falcata (Benth.) Speg. & Tree & -0.141 & -0.092 \\
Davilla elliptica A.St.-Hil. & Shrub & -0.181 & -0.132 \\
Diospyros hispida A.DC. & Shrub or tree & -0.104 & -0.100 \\
Kielmeyera coriacea Mart. \& Zucc. & Shrub or tree & -0.195 & -0.201 \\
Miconia albicans (Sw.) Steud. & Shrub or tree & -0.128 & -0.050 \\
Piptocarpha rotundifolia Baker & Shrub & -0.129 & -0.020 \\
Schefflera vinosa (Cham. \& Schltdl.) Frodin \& Fiaschi & Shrub or tree & -0.183 & -0.065 \\
Senna rugosa (G.Don) H.S.Irwin \& Barneby & Shrub & -0.138 & -0.110 \\
Siparuna guianensis Aubl. & Shrub or tree & -0.207 & -0.192 \\
Stryphnodendron polyphyllum Mart. & Tree & -0.128 & -0.080 \\
Xylopia aromatica Mart. & Shrub or tree & -0.138 & -0.115 \\
\hline
\end{tabular}


percentage, rate and informational entropy were calculated (Santana and Ranal, 2004) as follows:

- $\mathrm{G}(\%)=(\mathrm{N} / \mathrm{A}) \cdot 100$, where: $\mathrm{G}=$ germination percentage; $\mathrm{N}=$ number of germinated seeds; and $\mathrm{A}$ $=$ total number of sowed seeds.

- $\mathrm{R}=1 / \mathrm{t}$, where: $\mathrm{R}=$ the germination rate $\left(\right.$ days $\left.^{-1}\right)$; $\mathrm{t}=$ average time of germination $\left(\mathrm{t}=\Sigma\left(\mathrm{n}_{\mathrm{i}} \cdot \mathrm{t}_{\mathrm{i}}\right) / \Sigma \mathrm{n}_{\mathrm{i}}\right.$, where: $t_{i}=$ time of incubation, and $n_{i}=$ number of seeds germinated between two consecutive times of observation, $\left(\mathrm{t}_{\mathrm{i}}-1\right)$ and $\left.\left(\mathrm{t}_{\mathrm{i}}\right)\right)$.

- $\mathrm{E}=-\Sigma\left[\mathrm{f}_{\mathrm{i}} \cdot \log _{2}\left(\mathrm{f}_{\mathrm{i}}\right)\right]$, where $\mathrm{E}=$ informational entropy of germination, $f_{i}=$ relative germination frequency, and $\mathrm{f}_{\mathrm{i}}=\mathrm{n}_{\mathrm{i}} / \Sigma \mathrm{n}_{\mathrm{i}}, \mathrm{n}_{\mathrm{i}}=$ number of seeds germinated between two consecutive times of observation, $\left(\mathrm{t}_{\mathrm{i}}-1\right)$ and $\left(\mathrm{t}_{\mathrm{i}}\right)$.

\subsection{Osmotic potential}

The osmotic potentials of the extracts were measured (Micro-Osmette, model: 5004 automatic osmometer). A germination bioassay was set with the target species subjected to treatments of polyethylene glycol 6000 in concentrations of corresponding obtained osmotic potentials.

\subsection{Data analysis}

The experimental design was completely randomised with four repetitions. The data were compared by the Mann-Whitney test $(\alpha=0.05)$, using PAST version 2.5 software (Hammer et al., 2001).

\section{Results}

The plant extracts presented osmotic potential values between -0.020 and $-0.207 \mathrm{MPa}$ (Table 1$)$. The tested PEG-6000 solutions ( -0.1 and $-0.2 \mathrm{MPa})$ had no influence on lettuce and sesame germination percentages, rates and informational entropies.

Lettuce experiment results are shown in Table 2. Germinability reductions in relation to the witness were stronger under the effects of $D$. elliptica and M. albicans extracts from the dry season. All species extracts from both seasons (rainy and dry) delayed the germination in relation to the witness. However, the germination rate was lower for dry season extracts of six species (D. elliptica, $D$. hispida, K. coriacea, M. albicans, P. rotundifolia and $S$. vinosa). Germination entropy was higher for dry season extracts of four species (D. hispida, K. coriacea, $P$. rotundifolia and $S$. vinosa). D. elliptica was the only species that presented rainy season extract with higher negative effects on entropy than the dry season extract.

Sesame experiment results are shown in Table 3. No differences in germinability were observed in any treatments. The germination rate was decreased in 10 out of 11 species extracts. Three species (D. elliptica, $P$. rotundifolia and $S$. vinosa) presented higher inhibitions when collected in the dry season, compared with just one species (A.falcata) in the rainy season. Few differences in the germination entropy for this target species were observed. Four species increased entropy values, but only two species collected in the dry season had higher effects.

\section{Discussion}

The osmotic potential of an extract can present a negative effect on germination (Ferreira and Aquila, 2000). Some solutes alter water osmotic potential and uptake by the plant (Villela et al., 1991). According to the osmolarity control experiment, the studied cerrado species extracts did not show osmotic potential values (from -0.020 to

Table 2. Effects on lettuce (Lactuca sativa L.) germination by leaf crude extracts ( $10 \%$ concentration: weight/volume, with dry leaves and distilled water) from cerrado species (Anadenanthera falcata (Benth.) Speg., Davilla elliptica A.St.-Hil., Diospyros hispida A.DC., Kielmeyera coriacea Mart. \& Zucc., Miconia albicans (Sw.) Steud., Piptocarpha rotundifolia Baker, Schefflera vinosa (Cham. \& Schltdl.) Frodin \& Fiaschi, Senna rugosa (G.Don) H.S.Irwin \& Barneby, Siparuna guianensis Aubl., Stryphnodendron polyphyllum Mart., and Xylopia aromatica Mart.), after 10 days of bioassay.

\begin{tabular}{|c|c|c|c|c|c|c|}
\hline \multirow{2}{*}{ Species } & \multicolumn{2}{|c|}{ G(\%) } & \multicolumn{2}{|c|}{$R\left(\right.$ days $\left.^{-1}\right)$} & \multicolumn{2}{|c|}{$\mathbf{E}$} \\
\hline & Rainy & Dry & Rainy & Dry & Rainy & Dry \\
\hline A. falcata & $96.7 \pm 2.7$ & $95.8 \pm 5.0$ & $0.50 \pm 0.09$ & $0.46 \pm 0.02$ & $1.83 \pm 0.33$ & $1.94 \pm 0.15$ \\
\hline D. elliptica & $97.5 \pm 1.6$ & $24.2 \pm 19.7$ * & $0.17 \pm 0.01$ & $0.11 \pm 0.00 *$ & $2.83 \pm 0.31 *$ & $1.60 \pm 0.56$ \\
\hline D. hispida & $93.3 \pm 5.4$ & $83.3 \pm 8.2$ & $0.48 \pm 0.07$ & $0.15 \pm 0.02 *$ & $1.68 \pm 0.45$ & $3.10 \pm 0.15 \%$ \\
\hline K. coriacea & $93.3 \pm 6.1$ & $90.8 \pm 7.4$ & $0.46 \pm 0.04$ & $0.32 \pm 0.07 *$ & $1.79 \pm 0.37$ & $2.62 \pm 0.30 \%$ \\
\hline M. albicans & $88.3 \pm 4.3$ & $36.7 \pm 16.8 *$ & $0.28 \pm 0.03$ & $0.13 \pm 0.01 *$ & $3.21 \pm 0.25$ & $1.90 \pm 0.87$ \\
\hline P. rotundifolia & $93.3 \pm 6.1$ & $91.7 \pm 4.3$ & $0.50 \pm 0.03$ & $0.27 \pm 0.06^{*}$ & $1.71 \pm 0.22$ & $2.71 \pm 0.32 \%$ \\
\hline S. vinosa & $90.8 \pm 5.7$ & $94.2 \pm 7.4$ & $0.42 \pm 0.05$ & $0.17 \pm 0.05 \%$ & $2.29 \pm 0.24$ & $2.97 \pm 0.08 *$ \\
\hline S. rugosa & $90.8 \pm 3.2$ & $95.0 \pm 1.9$ & $0.49 \pm 0.02$ & $0.44 \pm 0.05$ & $1.86 \pm 0.17$ & $1.99 \pm 0.23$ \\
\hline S. guianensis & $92.5 \pm 3.2$ & $95.0 \pm 6.4$ & $0.22 \pm 0.02$ & $0.20 \pm 0.02$ & $2.91 \pm 0.09$ & $2.84 \pm 0.34$ \\
\hline S. polyphyllum & $95.8 \pm 4.2$ & $93.3 \pm 7.7$ & $0.48 \pm 0.05$ & $0.54 \pm 0.02$ & $1.72 \pm 0.30$ & $1.87 \pm 0.17$ \\
\hline$X$ aromatica & $93.3 \pm 6.1$ & $93.3 \pm 7.2$ & $0.30 \pm 0.03$ & $0.30 \pm 0.04$ & $2.33 \pm 0.23$ & $2.51 \pm 0.56$ \\
\hline Witness & $99.2 \pm 1.7$ & $97.5 \pm 3.2$ & $0.74 \pm 0.13$ & $0.72 \pm 0.14$ & $1.26 \pm 0.49$ & $1.21 \pm 0.25$ \\
\hline
\end{tabular}

Mean \pm standard deviation. G(\%): germinability; R: Germination rate; E: informational entropy of germination; Rainy: rainy season; Dry: dry season. Values \pm standard deviation. Difference from witness (italic bold numbers) and between rainy/dry seasons (*) by Mann-Whitney test $(\alpha=0.05)$. 
Table 3. Effects on sesame (Sesamum indicum L.) germination by leaf crude extracts $(10 \%$ concentration: weight/volume, with dry leaves and distilled water) from cerrado species (Anadenanthera falcata (Benth.) Speg., Davilla elliptica A.St.-Hil., Diospyros hispida A.DC., Kielmeyera coriacea Mart. \& Zucc., Miconia albicans (Sw.) Steud., Piptocarpha rotundifolia Baker, Schefflera vinosa (Cham. \& Schltdl.) Frodin \& Fiaschi, Senna rugosa (G.Don) H.S.Irwin \& Barneby, Siparuna guianensis Aubl., Stryphnodendron polyphyllum Mart., and Xylopia aromatica Mart.), after 10 days of bioassay.

\begin{tabular}{|c|c|c|c|c|c|c|}
\hline \multirow{2}{*}{ Species } & \multicolumn{2}{|c|}{$G(\%)$} & \multicolumn{2}{|c|}{$R\left(\right.$ days $\left.^{-1}\right)$} & \multicolumn{2}{|c|}{ Entropy } \\
\hline & Rainy & Dry & Rainy & Dry & Rainy & Dry \\
\hline A. falcata & $98.3 \pm 3.3$ & $100.0 \pm 0.0$ & $0.55 \pm 0.03 *$ & $0.65 \pm 0.05$ & $1.40 \pm 0.35$ & $1.10 \pm 0.51$ \\
\hline D. elliptica & $94.2 \pm 4.2$ & $96.7 \pm 4.7$ & $0.54 \pm 0.06$ & $0.39 \pm 0.05 *$ & $1.42 \pm 0.43$ & $2.14 \pm 0.28$ \\
\hline D. hispida & $100.0 \pm 0.0$ & $100.0 \pm 0.0$ & $0.68 \pm 0.03$ & $0.63 \pm 0.05$ & $0.74 \pm 0.41$ & $1.31 \pm 0.25$ \\
\hline K. coriacea & $97.5 \pm 3.2$ & $99.2 \pm 1.7$ & $0.66 \pm 0.00$ & $0.62 \pm 0.12$ & $0.20 \pm 0.28$ & $1.10 \pm 0.27$ \\
\hline M. albicans & $96.7 \pm 3.8$ & $98.3 \pm 1.9$ & $0.65 \pm 0.02$ & $0.61 \pm 0.13$ & $0.85 \pm 0.09$ & $1.55 \pm 0.20 *$ \\
\hline P. rotundifolia & $99.2 \pm 1.7$ & $97.5 \pm 3.2$ & $0.76 \pm 0.03$ & $0.60 \pm 0.06 *$ & $0.95 \pm 0.15$ & $1.06 \pm 0.43$ \\
\hline S. vinosa & $98.3 \pm 1.9$ & $100.0 \pm 0.0$ & $0.64 \pm 0.05$ & $0.42 \pm 0.07 *$ & $0.76 \pm 0.70$ & $2.27 \pm 0.42 *$ \\
\hline S. rugosa & $98.3 \pm 3.3$ & $98.3 \pm 1.9$ & $0.67 \pm 0.02$ & $0.69 \pm 0.03$ & $0.35 \pm 0.09$ & $0.80 \pm 0.23$ \\
\hline S. guianensis & $95.8 \pm 4.2$ & $98.3 \pm 1.9$ & $0.31 \pm 0.04$ & $0.32 \pm 0.06$ & $2.61 \pm 0.29$ & $2.51 \pm 0.21$ \\
\hline S. polyphyllum & $98.3 \pm 3.3$ & $100.0 \pm 0.0$ & $0.64 \pm 0.02$ & $0.67 \pm 0.04$ & $0.35 \pm 0.17$ & $0.85 \pm 0.24$ \\
\hline$X$. aromatica & $95.0 \pm 1.9$ & $100.0 \pm 0.0$ & $0.58 \pm 0.09$ & $0.60 \pm 0.07$ & $1.33 \pm 0.71$ & $1.19 \pm 0.27$ \\
\hline Witness & $95.0 \pm 3.3$ & $100.0 \pm 0.0$ & $0.84 \pm 0.15$ & $0.82 \pm 0.02$ & $0.83 \pm 0.62$ & $1.08 \pm 0.13$ \\
\hline
\end{tabular}

Mean \pm standard deviation. G(\%): germinability; R: Germination rate; E: informational entropy of germination; Rainy: rainy season; Dry: dry season. Values \pm standard deviation. Difference from witness (italic bold numbers) and between rainy/dry seasons $(*)$ by Mann-Whitney test $(\alpha=0.05)$.

$-0.207 \mathrm{MPa}$ ) that could influence lettuce and sesame germination processes.

The germination of lettuce and sesame were more impacted by dry season extracts. Decreases in the percentages and rates were more evident in target species subjected to dry season extracts. Stronger inhibitions occurred on the germination rate rather than the percentage. Higher germination entropy values and imbibition time distributions were verified, characterising lower germination synchrony. In addition to germinability, germination rate, homogeneity and synchrony are factors that show the level of organisation or disorder in the chemical reactions of the germination process (Ferreira, 2004; Santana et al., 2006). Changes in germination parameters can result from the effects of several physiological processes: membrane permeability, DNA transcription and translation, second messengers function, respiration, enzymes and receptors conformation (Ferreira, 2004; Rizvi and Rizvi, 1992). Slower germination plants can present reduced size (Jefferson and Pennacchio, 2003), leading to greater susceptibility to stress and less chances in resource competition. The species' sensibility to phytotoxins under laboratory conditions is dependent of biochemical/physiological characteristics (Kobayashi, 2004), seed size and structure.

Because phytotoxic effects on the germination processes can be species dependent (Oliveira, 2009), two target species (lettuce and sesame) were selected. Dependency on both donor and receptor species was observed. Donor species differed in their effects; some species presented inhibitions on none, some or all of the germination parameters. The receptor species sesame was less sensible compared to lettuce but presented similar results of higher negative effect when subjected to dry season extracts. Lettuce has been considered to be too sensitive for allelopathic bioassays, and this study detected more differences in phytotoxic activities between the extracts from the rainy and dry season collection periods.

Cerrado presents a dry season that lasts up to six months (Gottsberger and Silberbauer-Gottsberger, 2006). The soil is subjected to a water deficit at the surface layers due to increasing atmospheric evaporation demand and solar incidence (Franco, 2002; Haridasan, 2001) that represents a potential stressful time for plants (Sarmiento, 1996). Biotic and abiotic stressful conditions alter the production of allelochemicals. Climatic parameters can affect the production of flavonoids (Chaves and Escudero, 1999) and increase cumarine concentration in some plants (Blanco, 2007). Flavonoids are found in nearly all vascular plants, and some flavonoids can affect germination (Iwashina, 2003). In addition, plants are rarely exposed to only one stress (Einhellig, 1999). Other factors, which possibly interact in this environment, include competition processes, microorganism activity, vegetation burning and leaves deciduousness influenced by seasonality.

Environments in stressful conditions may restrict plant growth, photosynthetic ratio and accumulate nonstructural carbohydrates. This may be one of the reasons contributing to increased production of carbon based defensive substances, which are secondary metabolism derivatives (Chaves and Escudero, 1999). The carbon/ nutrient balance is confirmed because species growing in low nutrient/water availability environments produce high levels of tannins and phenols (Bryant et al., 1983; Waring et al., 1985).

Allelopathy can present an important function in arid environments. Allelochemicals in arid environments remain in the soil longer compared with humid environments, and their effects can be intensified when combined with the 
impact of low soil moisture (Einhellig, 1999). The production of these compounds can increase in environments where burning is common, most likely due to physical damage to plants. Increased production can provide a higher inhibition on competitor/receptor plants and characterise an important plant defense mechanism (Einhellig, 1999; Einhellig, 2004).

The difference observed in the results can be due to species exposure to climate alterations or other seasonal stresses that induced greater allelochemical production. The allelopathic activity on both receptor species increased during the dry season for the majority of the studied cerrado plant species. Lettuce was the most sensible receptor species, and the germination rate was the most sensible parameter that showed this difference. These distinct responses to stressful situations in a complex environment, such as the Brazilian cerrado, may support species establishment and survival. Therefore, studies of other species are necessary to better understand this topic.

\section{Acknowledgements}

We are grateful to $\mathrm{CNPq}$ (Conselho Nacional de Desenvolvimento Científico e Tecnológico) for supporting the research for the first author and for funding the Research Productivity Grant for the last author.

\section{References}

BLANCO, JA., 2007. The representation of allelopathy in ecosystem-level forest models. Ecological Modelling, vol. 209, no. 2-4, p. 65-77. http://dx.doi.org/10.1016/j.ecolmodel.2007.06.014.

BRYANT, JP., CHAPIN, FS. and KLEIN, DR., 1983. Carbon/ nutrient balance of boreal plants in relation to vertebrate herbivory. Oikos, vol. 40, no. 3, p. 357-368. http://dx.doi.org/10.2307/3544308.

CHAVES, N. and ESCUDERO, C., 1999. Variation of flavonoid syntheis induced by ecological factors. In INDERJIT, DAKSHINI, KMM. and FOY, CL. Principles and Practices in Plant EcologyAllelochemical Interactions. Boca Raton: CRC Press. p. 267-285.

DURIGAN, JC. and ALMEIDA, FLS., 1993. Noções sobre a alelopatia. Jaboticabal: Funep. 28 p.

EINHELLIG, FA., 1999. An integrated view of allelochemicals amid multiple stresses. In INDERJIT, DAKSHINI, KMM. and FOY, CL. Principles and practices in plant ecology: Allelochemical interactions. Boca Raton: CRC Press. p. 479-494.

EINHELLIG, FA., 2004. Mode of allelochemical action of phenolic compounds. In MACÍAS, FA., GALINDO, JCG., MOLINILLO, JMG. and CUTLER, HG. Allelopathy - Chemistry and mode of action of allelochemicals. Washington: CRC Press. p. 217-238.

EMPRESA BRASILEIRA DE PESQUISA AGROPECUÁRIA - EMBRAPA, 2012. Condições meteorológicas. Available from: $<$ http://www.cppse.embrapa.br/dados-meteorologicos $>$. Access in: 28 May 2012.

FERREIRA, AG., 2004. Interferência: competição e alelopatia. In FERREIRA, AG. and BORGHETTI, F. Germinação do básico ao aplicado. Porto Alegre: Artmed. p. 251-262.
FERREIRA, AG., 2005. Alelopatia: sinergismo e inibição. In NOGUEIRA, RJMC., ARAÚJO, EL., WILLADINO, LG. and CAVALCANTE, UMT. Estresses ambientais: danos e beneficios em plantas. Recife: UFRPE, Imprensa Universitária. p. 433-440.

FERREIRA, AG. and AQUILA, MEA., 2000. Alelopatia: uma área emergente da ecofisiologia. Revista Brasileira de Fisiologia Vegetal, vol. 12, p. 175-204.

FRANCO, AC., 2002. Ecophysiology of woody plants. In OLIVEIRA, PS. and MARQUIS, RJ. The cerrados of Brazil: Ecology and natural history of a neotropical savanna. Irvington: Columbia University Press. p. 178-197.

GOBBO-NETO, L. and LOPES, NP., 2007. Plantas medicinais: fatores de influência no conteúdo de metabólitos secundários. Quimica Nova, vol. 30, no. 2, p. 374-381. http://dx.doi.org/10.1590/ S0100-40422007000200026.

GOTTSBERGER, G. and SILBERBAUER-GOTTSBERGER, I., 2006. Life in the cerrado: origin, structure, dynamics and plant use: a South American tropical seasonal ecosystem. Ulm: Reta Verlag. 277 p.

GROSS, EM., 2003. Allelopathy of Aquatic Autotrophs. Critical Reviews in Plant Sciences, vol. 22, no. 3-4, p. 313-339. http:// dx.doi.org/10.1080/713610859.

HAMMER, Ø., HARPER, DAT. and RYAN, PD., 2001. PAST: Paleontological Statistics Software Package for Education and Data Analysis. Palaeontologia Electronica, vol. 4, no. 1, p. 1-9.

HARIDASAN, M., 2001. Nutrient cycling as a function of landscape and biotic characteristics in the cerrado of central Brazil. In MCCLAIN, ME., VICTORIA, RL. and RICHEY, JE. The biogeochemistry of the Amazon basin. New York: Oxford University Press. p. 68-83.

INDERJIT and CALLAWAY, RM., 2003. Experimental designs for the study of allelopathy. Plant and Soil, vol. 256, no. 1, p. 1-11. http://dx.doi.org/10.1023/A:1026242418333.

INTERNATIONAL ALLELOPATHY SOCIETY - IAS, 2013. Constitution and Bylaws. Available from: $<\mathrm{http}: / / \mathrm{www}$-ias.uca. es/bylaws.htm>. Access in: 22 May 2013.

INTERNATIONAL PLANT NAMES INDEX - IPNI, 2012. Available from: <http://www.ipni.org/>. Access in: 26 Apr. 2013.

IWASHINA, T., 2003. Flavonoid function and activity to plants and other organisms. Uchu Seibutsu Kagaku, vol. 17, no. 1, p. 24-44. http://dx.doi.org/10.2187/bss.17.24. PMid:12897458

JEFFERSON, LV. and PENNACCHIO, M., 2003. Allelopathic effects of foliage extracts from four Chenopodiaceae species on seed germination. Journal of Arid Environments, vol. 55, no. 2, p. 275-285. http://dx.doi.org/10.1016/S0140-1963(03)00028-4.

KIKVIDZE, Z., MICHALET, R., BROOKER, RW., CAVIERES, LA., LORTIE, CJ., PUGNAIRE, FI. and CALLAWAY, RM., 2011. Climatic drivers of plant-plant interactions and diversity in alpine communities. Alpine Botany, vol. 121, no. 1, p. 63-70. http://dx.doi.org/10.1007/s00035-010-0085-x.

KOBAYASHI, K., 2004. Factors affecting phytotoxic activity of alelochemicals in soil. Weed Biology and Management, vol. 4, no. 1, p. 1-7. http://dx.doi.org/10.1111/j.1445-6664.2003.00112.x.

KÖEPPEN, W., 1948. Climatologia. México: Fondo de Cultura Económica. 478 p.

OLIVEIRA, SCC., 2009. Estudo alelopático de espécies do gênero Solanum do Distrito Federal. São Carlos: Departamento 
de Botânica, Universidade Federal de São Carlos. 163 p. Tese de Doutorado.

ORLANDI, L., BARBOSA, S., ROCHA, LC., RODRIGUES, LCDA., BEIJO, LA. and SILVA, GA., 2010. Efeito do extrato foliar de murici-pequeno obtido em diferentes épocas do ano sobre aspectos vegetativos do bioteste alface. In Anais do XIX congresso de Pós-graduação da UFLA, Reunião Regional da SBPC: Ciência, Tecnologia, Inovação e o Município, 2010. Lavras. Lavras: UFLA.

PENG, SL., CHEN, ZQ., WEN, J. and SHAO, H., 2004. Is allelopathy a driving force in forest sucession? Allelopathy Journal, vol. 14, p. 197-204.

RIZVI, SJH. and RIZVI, V. (Eds.), 1992. Allelopathy: basic and applied aspects. London: Chapman \& Hall. 480 p. http://dx.doi. org/10.1007/978-94-011-2376-1.

SANTANA, DG. and RANAL, M., 2004. Análise da germinação - um enfoque estatístico. Brasília: Editora Universidade de Brasília. 248 p.
SANTANA, DG., RANAL, MA., MUSTAFA, PCV. and SILVA, RMG., 2006. Germination measurements to evaluate allelopathic interactions. Allelopathy Journal, vol. 17, no. 1, p. 43-52.

SARMIENTO, G., 1996. Biodiversity and water relations in tropical savannas. In SOLBRIG, OT., MEDINA, E. and SILVA, JF. Biodiversity and savanna ecosystem processes: a global perspective. Berlin: Springer Verlag. p. 61-75. http://dx.doi. org/10.1007/978-3-642-78969-4_4.

TAIZ, L. and ZEIGER, E., 2010. Plant Physiology. 5th ed. Sunderland: Sinauer Associates Inc. 782 p.

VILLELA, FA., DONI FILHO, L. and SEQUEIRA, EL., 1991. Tabela de potencial osmótico em função da concentração de polietileno glicol 6000 e da temperatura. Pesquisa Agropecuaria Brasileira, vol. 26, no. 11-12, p. 1957-1968.

WARING, RH., MCDONALD, AJS., LARSSON, S., WIREN, A., ARWIDSSON, E., ERICSSON, A. and LOHAMMAR, T., 1985. Differences in chemical composition of plant growing at constant relative growth rates with stable mineral nutrition. Oecologia, vol. 66, no. 2, p. 157-160. http://dx.doi.org/10.1007/BF00379849. 